\title{
Rule of Law Indicators in Context: An Empirical Evaluation of GTZ Legal Advisory in Beijing
}

Vishnu Sridharan *

Much has been written about the general ability (or lack thereof) of international development organizations to effectively monitor and evaluate the impact of their Rule of Law projects on the ground. However, less research has focused on particular development organizations' methods of project evaluation, the politics behind them and their strengths and weaknesses. This paper offers such an analysis of the evaluation methods of GTZ Legal Advisory in Beijing. After describing the work of GTZ in general and its Legal Advisory in particular, the paper offers a detailed evaluation of the tools that it uses to gauge the impact of its projects on the ground. What is gained from such a particularized analysis is a deeper understanding of both the donor politics and organizational tradeoffs inherent in monitoring and evaluation decisions, two factors often given insufficient attention in more theoretical discussions.

\section{Keywords}

Rule of Law, GTZ, monitoring and evaluation, China, international development.

\section{Introduction}

Although the rule-of law movement is over a half-century old, fundamental questions remain as to its effectiveness and even its goals. ${ }^{1}$ During its inception after World War II, rule of law practitioners aimed to create legal systems that would "displace colonial

* Vishnu Sridharan is currently a Rule of Law Consultant in Beijing. B.A.(Columbia), J.D.(Stanford). The author may be contacted at: vishnus@stanford.edu/Address: 650 S. 43rd Street, Boulder, CO 80305 USA

1 This paper is the result of an internship conducted during the summer of 2008 with GTZ Legal Advisory in Beijing. 
and customary legal regimes. ${ }^{2}$ Over time, the movement has had various focuses, such as to advocate for human rights and constitutional protections and establish market economies in post-Communist and transitional countries. ${ }^{3}$ Today's movement maintains these earlier characteristics in addition to appropriating a slew of new ones, such as "relieving poverty, sustaining development and conserving social capital." 4

However, in spite of the rich, variegated history of rule of law work - and possibly because of it - there has been a "widening gap" between theory and practice, with disturbingly scant attention paid to measuring baselines of performance and the interconnectedness of social, economic, political and legal development. 5 This gap has left many scholars and practitioners unable to know whether the massive resources being allocated to these projects are being put to their best use, or even any use at all. In the words of Thomas Heller,

What is absent in the rule of law-development theory nexus is a particularized account of either the preexisting roles and structures of legal institutions in the political economies that are the objects of reform, or the dynamics of transition that will affect the prospects of effective change. 6

Independent of these abstract questions, we must first answer the baseline question of whether a set rule of law projects actually has their intended effects on the ground. In fact, an account of the preexisting roles of the legal institutions and the expected dynamics of effective change are both topics that arguably should be thoroughly addressed before a development organization invests in the promotion of the rule of law.

As Dani Rodrik has persuasively argued in the context of economic reforms, the greatest successes in institution building have relied upon "a mix of standard and nonstandard policies that are well attuned to the reality on the ground." 7 In order to engage in the "pragmatic innovation" 8 that Rodrik advocates, however, one needs to be fully cognizant of not only the current state of institutions, but, just as importantly, the

The author owes countless thanks to the staff of GTZ, in particular to Dr. Hinrich Julius for his invaluable comments and suggestions on earlier drafts.

2 Thomas Heller, An Immodest Postscript, in Beyond Common Knowledge: Empirical Approaches to The Rule of LAW 382-3 (Thomas Heller \& Erik Jensen eds., 2004).

3 Id.

$4 \quad I d$.

5 Erik Jensen \& Thomas Heller, Introduction, in Beyond Common Knowledge: Empirical Approaches to The Rule of LAW 12 (2004).

6 Id. at 13 .

Dani Rodrik, One Economics, Many Recipes: Globalization, Institutions, and Economic Growth 35 (2007).

Id. at 41 . 
effects that one's programs and policies have had and are continue to have on them. Rodrik points out that the transition path to so-called "best institutions" is a rocky one that requires "incessant changes interacting with initial conditions." 9 Thus, in order for as any rule of law organization to experiment with transitional legal institutions in attempts to modify and improve them, it must be acutely aware of the effects that its activities are having on the institutions themselves, in addition to all the institutions with which the legal system is connected.

Sadly, the current state of many rule of law organizations leaves much to be desired on this front. Although these organizations may not be vulnerable to Heller's critique that they have "a set of clear objectives but leave obscure both the theory underlying those objectives and the methods of reaching them," 10 they may be guilty of an even more fundamental flaw. These are the organizations that, while clear about their methods of reaching their objectives, lack adequate tools to gauge whether their methods are successful. It is this gap - the gap between rule of law projects and measurable progress - that is the topic of this paper.

Specifically, this paper will examine the extent to which Deutsche Gesellschaft für Technische Zusammenarbeit ("GTZ") Legal Advisory Service in Beijing is able to measure the impact of its projects on the ground, especially as related to its grander mission of promoting the rule of law in China. GTZ's programming in China is of particular importance not just because of the large amount of development funds that pour in from around the globe, but also because of the hopes that many pin to the development of China's judicial system. At the very least, companies hope that a greater adherence to the rule of law can help normalize contractual and business relations, reduce investment risks and boost profits. In addition, many hope that if legislation attains a greater importance, government officials will have to respect it more and thus will have less scope for the discretion that often leads to corruption. Lastly - probably the most idealistically - some imagine that stronger legal protections will grant citizens the scope to express and associate themselves freely, thus strengthening civil society and drastically limiting the state's power to interfere in the lives of the individual.

This paper will first give an overview of GTZ in general, and its legal advisory service in particular. To follow, it will discuss in detail the manner in which GTZ evaluates its own projects and progress toward its stated goals. Next, the paper will explore the strengths and weaknesses of GTZ's measurement tools in the context of China' s legal system. The paper will close with conclusions. 


\section{What is GTZ?}

\section{A. Definition of GTZ}

GTZ is an international non-profit cooperation enterprise that is owned by German government and aims to "promote cooperation which contributes to sustainable development throughout the world." 11 Similar to the relationship between United States Agency for International Development and the US, GTZ mixes international development efforts with the support for German foreign policy objectives. 12 The enterprise was incorporated under private law in 1975 and is headquartered in Eschborn near Frankfurt.

Although the German Federal Ministry for Economic Cooperation and Development ("BMZ") is its major client, GTZ also receives work from other German ministries, the governments of other countries, and international organizations such as the European Commission, the United Nations and the World Bank.13 GTZ is not a forprofit corporation, and all of its funds are employed in furtherance of its developmental agenda. GTZ works in over 120 countries in Africa, Asia, Latin America, and Eastern Europe. To get a sense of the scale of its operations, in 2007 GTZ's business volume was over one billion Euros ${ }^{14}$ (approximately 1.2 billion US dollars), which was a 15 percent increase from 2006.

For the past 25 years, GTZ has been working in China "to help foster China's transition to a society based on the Rule of Law." 15 GTZ's work in China falls into two broad categories: "sustainable economic development" and "environmental policy, protection and sustainable use of natural resources." 16 Environmental projects include sustainable forest management, wind energy training, management of obsolete pesticides, sustainable agro-biodiversity, energy efficiency, sustainable urban development and environmental protection in the coal and power plan sector. ${ }^{17}$ Economic development projects originally focused on vocational training and poverty monitoring, and evolved to address asset and equity market reform and management

\footnotetext{
GTZ, Corporate Identity, available at http://www.gtz.de/en/unternehmen/1716.htm (last visited on Oct. 8, 2009).

GTZ, Corporate Profile, available at http://www.gtz.de/en/unternehmen/1698.htm (last visited on Oct. 18, 2009). 
training. GTZ also has projects that cover corporate social responsibility, postal system reform and legal advising, 18 the topic of this paper.

\section{B. GTZ Legal Advisory}

Beginning in 1986, Germany's development cooperation with China expanded beyond purely economic matters into purely legal ones. ${ }^{19}$ From 1986 to 2000, the cooperation was involved in both constitutional and administrative law, with a strong focus on labor and social security, and in 2000, the "German-Chinese Dialogue on the Rule of Law" significantly expanded the scope of legal cooperation and multiplied its activities, projects and programs. 20 This "Dialogue" was agreed upon between Chancellor Gerhard Schroeder and then-Chinese Prime Minister Zhu Rongji on June 30, 2000, and the subsequent document signed by the German and Chinese ministers detailed the following specific areas of cooperation: Administrative Law, Civil and Commercial Law, Labor and Social Security Law, improvement of the implementation of existing laws and regulations, protection of citizens' legal rights, and combating corruption and white collar crime.21 More specifically, the progression of GTZ's legal work is as follows: in 1986, GTZ began work with IP Law; in 1994, it moved to Labor and Social Security Law; in 1998, it began with Commercial Laws; in 2000, Administrative Law; in 2001, judicial trainings; in 2004, Public Budgeting and Civil Law (Civil Procedure); and in 2006, IP Law.

At the time, Germany was very interested in this legal dialogue with China because dealing with human rights issues in the PRC had been central to the Social Democrats ("SPD") or Green Coalition. In fact, their coalition treaty clearly stated that "respect for and implementation of international human rights standards as contained in the Universal Declaration of Human Rights constitutes the central guideline for German foreign policy.” 22 On the Chinese side, WTO negotiations were ongoing, and Premier Zhu was quite receptive to funding and foreign expertise in restructuring China's judicial system in areas crucial to WTO accession. ${ }^{23}$

GTZ's Legal Advisory Service in China presently engages in the following activities: symposia and workshops, some individual consultations, study tours, training courses,

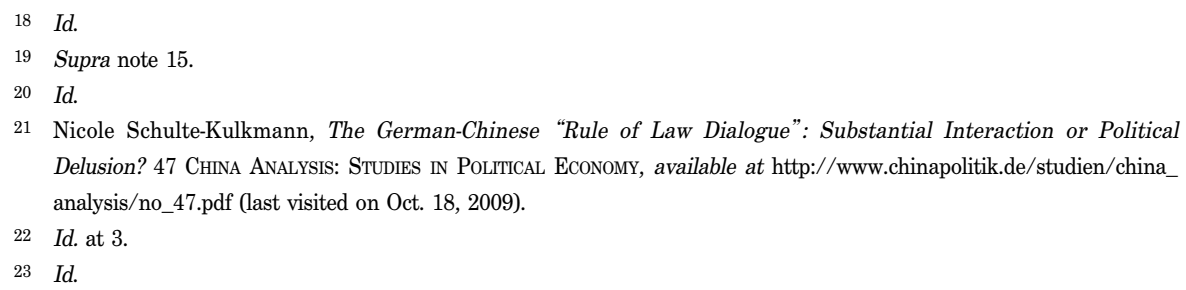


publications of advisory and training material and scholarships.24 At symposia and workshops, foreign experts and practitioners who specialize in legal fields of interest to the Chinese discuss short papers and other topics with Chinese partners. Individual consultations occur as and when necessary to prepare, implement and evaluate these symposia. Study Tours to Europe give Chinese politicians, officials and other experts the opportunity to conduct research in connection with specific legislative projects.

One to four week training courses are conducted for Chinese ministry officials and judges with regards to legal implementation, with particular attention to economic laws and the Rule of Law in general. Publications following these symposia and training courses aim to promote transparence and the sustainability of legal advice. Scholarships for masters programs in economic law are also offered by GTZ's legal advisory service. 25

GTZ Legal Advisory has three central areas of cooperation with its Chinese counterparts: drafting and implementing legislation with the Budget Affairs Commission ("BAC") and Legal Affairs Commission ("LAC") of the National People's Congress, training judges in cooperation with the National Judges College, and strengthening Intellectual Property Rights in cooperation with the National Office of Rectification and Standardization of Market Economic Orders and the State Office of Intellectual Property Protection. ${ }^{26}$ GTZ also has a set amount of "open funds" to support follow-up measures with prior partners such as FEC and MOFCOM, in addition to projects that arise unexpectedly, such as the cooperation with the Ministry of Civil Affairs to promote a national social welfare system and an improved legal framework for the establishment of NGOs. ${ }^{27}$

Specific examples of GTZ's four main activities, drafting and revision of laws, trainings, symposia, and study tours, are given below.

\section{Drafting and Revision of Laws}

Assistance with the drafting and revision of laws is one of the two central pieces of GTZ's Legal Advisory work in Beijing. The list of laws that GTZ has helped to shape is quite impressive, with two of the most recent examples being the Corporate Income Tax Law, which came into force on January 1, 2008, and the Property Law which came into force on October 1, 2007.28 Before the latest tax law, China lacked unified legislation regarding the taxation of corporations, which led to a substantially higher actual tax rate

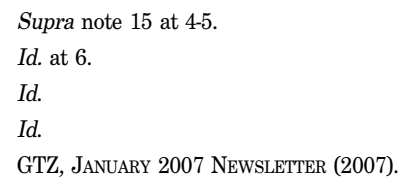


for domestic companies. Under the new law, all companies will be taxed equally, and both domestic and foreign firms will be able to access preferential tax treatment. ${ }^{29}$ The new property law has been heralded as protecting both private and public property equally, in addition to regulating detailed questions of movable and immovable property for the first time, for instance the extension of acquired land use rights and the legal relationship among flat owners and developers. 30 However, agricultural land use rights are not fully transferable under the property law, nor can the property be used as collateral. ${ }^{31}$

\section{Trainings}

The other of GTZ's integral means of pursuing its legal reform agenda is through shortand long-term trainings, which it conducts both for judges and government officials. Trainings for judges are conducted through the National Judges College (NJC). For instance a short-term training course on Criminal Law was held from January 22nd to 26th in Beijing.32 Over 40 experienced judges from various provinces in China attended, both to gain knowledge for themselves and aid in their training of younger judges in their respective court district ("training-of-trainers method"). These lectures focused on criminal case studies, and specifically demonstrate how to apply German legal methodology in resolving disputes according to Chinese Criminal Procedure Law. This short-term training course was a follow-up to a long-term training course in November/December 2006.33

GTZ also conducts trainings of high-level government officials with respect to complicated legislation and the rule of law in general. For instance, together with the Ministry of Commerce ("MOFCOM"), GTZ organized a long-term training course of commercial laws in Beijing from March 5th to 30th, 2006.34 About 40 officials from various departments of MOFCOM from Beijing and nine other provinces participated in the course, which focused on topics related to their daily work such as contract law, guarantee law, company law and intellectual property law, with a particular focus on the implementation of these laws according to principles of the rule of law. 35 The training was mainly conducted through discussion of case studies, mock trials and the drafting of contracts. 36

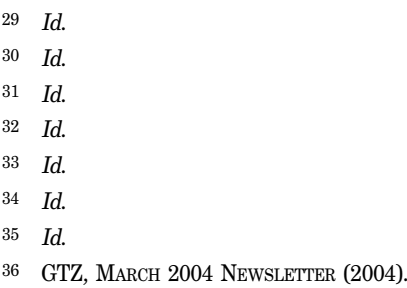




\section{Symposia}

The symposia that GTZ sponsor connect integrally with their other activities. For instance, a symposia on Property Law was held on April 24 and 25, 2006 in Zhengzhou, China to address public criticism of the first draft of the law that was set to be enacted in March 2006. This symposium was part to the aforementioned work that GTZ was conducting in advising on the drafting and revision of the law (and would later be followed by judges' and government officials' trainings about its implementation). ${ }^{37}$ Domestic and foreign experts met with members of the Legislative Affairs Commission ("LAC") of the Standing Committee of the National People's Congress ("NPC") to discuss the fervent attacks from the public on the original draft, which were not so much aimed at any particular provision of the legislation as at its "seemingly capitalistic spirit." 38 Much work was done during the symposia to address this criticism, in addition to the contention that the law violated the General Principles of Civil Law by allowing the destruction of the system of public ownership and promoting privatization. 39

An example of a symposium that occurred earlier in the drafting process was the Symposium on Social Security Law, which was held on March 31'st and April 1st, 2008 in Beijing. 40 Attendees included members of the drafting team of the Department of State Law of the LAC, experts from relevant agencies, ministries and universities in China, and experts from Germany. The LAC had already finished a first draft of the Law, although they said that the law would face significant revision before its passage. 41 The symposium aimed to familiarize the participants with the problems and solutions with Germany's Social Security law, in addition to those of other European countries. Specifically, the symposium addressed topics such as the responsibilities of the government, the payment of Social Security contributions and the administration and supervision of Social Security funds. 42

\section{Study Tours}

After the aforementioned March 2008 Symposium on Social Security Law GTZ Legal Advisory Service conducted a study tour to Germany and France.43 From May $4^{\text {th }}$ till the $13^{\text {th }}$, members of the LAC visited the Federal Ministry of Health, Federal Ministry of

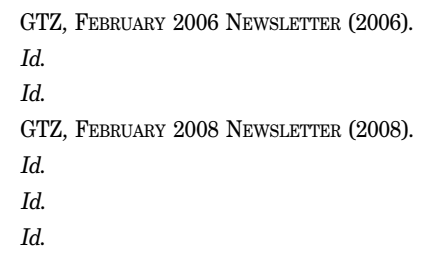


Labor and Social Security, the Federal Social court as well as other legal and administrative authorities. As was the case during the symposium, LAC members were primarily interested in issues related to retirement schemes, such as "the pros and cons of the adjustable contribution procedure (Umlageverfahren) and the formation of coverage capital (Kapitaldeckungsverfahren)." 44

In addition, to more deeply inform the above-mentioned Taxation law that came into effect in January of 2008, GTZ took a drafting team from the LAC to Germany and Sweden from October 9th to $20^{\text {th }}, 2005.45$ (This study tour was itself a follow-up to a symposium on the same topic in June 2005.) 46 On the trip, the drafting team had the opportunity to discuss tax law with members of governmental and parliamentary bodies on the central and local level in Germany and Sweden. ${ }^{47}$ In this case, the Swedish model of transfer payment, in which one central agency collected from countrywide branches, contrasted with that of Germany, in which taxes are primarily collected at the provincial and local level.48

\section{GTZ Legal Advisory Service's Measurement and Evaluation Tools}

\section{A. Drafting and Revision of Laws}

GTZ's measurement tools with respect to their projects that aid in the drafting and revision of laws are commendable. It constantly writes in depth reports about the influence of their experts on the Chinese drafting process and also examines final legislation for evidence of their efforts.

One example of the latter, the in-depth analysis of a final piece of legislation, the report that Liu Junhai wrote on August 8, 2001 entitled, "Research report on the suggestions made by foreign experts to be adopted in the draft of the Chinese Government Procurement Law 49 ." The introduction reads:

The foreign experts participating in the Sino-German Symposium on Government Procurement held in Xi' an from July 17th to 22nd, 2001 have made great suggestions .

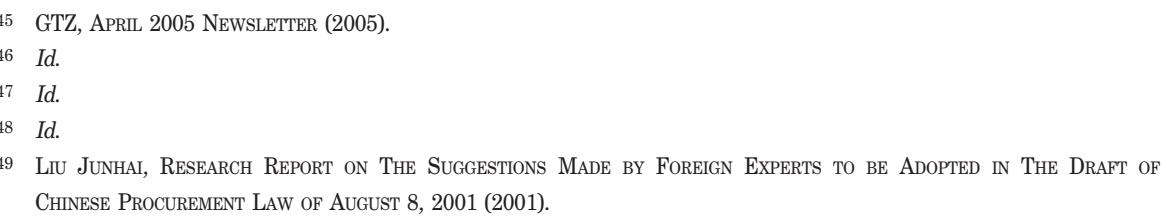


and recommendations on furthering polishing the draft of Chinese Government Procurement Law of June 22, 2001. Most of the suggestions and recommendations have been adopted in the draft of Chinese Government Procurement Law of August $8^{\text {th }}$ 2001. However, some of them have not been adopted due to some other understandable consideration. This report aims at pointing out the suggestions and recommendations having been adopted in the draft of Chinese Government Procurement Law of August 8, 2001, explaining the reasons for these suggestions and recommendations not having been adopted, and trying to make some academic comments regarding the legislative attitude. 50

The paper then comments on each article of the legislation, pointing out exactly how the experts' recommendations were or were not incorporated into the final law, including analysis as to what the legislators' hesitations were and how they responded to the experts. For instance, with respect to Article 1 of that same Procurement law, the report reads:

The foreign experts suggested that Article 1 should "explicitly create and ensure the right of the bidders and suppliers in the public procurement process." This suggestion was basically adopted by the drafters. Article 1 of the Draft of August 8, 2001 added a sentence "protecting the legitimate rights and interests of all participants in the procurement process". The wording all participants not only includes government procurement entities or agencies, but also includes the bidders and suppliers...

The foreign experts also suggested that Article 2 should "list principles of transparency, fair dealing and avoiding all kinds of improper conduct, not just corruption." This suggestion was partially endorsed by the drafters, as "the principle of promoting transparency" is listed in Article 3, instead of Article 1of the Draft of August 8, 2001. The rationale here is that "transparency" was considered a principle, but not a purpose itself. However, the word "fair dealing and avoiding all kinds of improper conduct" was not adopted, as corruption is regarded as the most serious problem among all kinds of improper conduct in the government procurement process in China. 51

An example of an overview report on the effect that GTZ' s advising had over the lifespan of drafting a bill is entitled "Evaluation of the Advisory Activities in the Process of Establishing the Law of the P.R. China on Promoting Small and Medium-sized Enterprising ("SME Promotion Law" or "SMEPL"). 52 The contents of the first two 
sections are as follows:

I. The SME Promotion Law's Origin and Purpose

II. The Project's Contribution to the SME Promotion and Law's Elaboration

1. First Symposium (1999) and Model Law (ML)

2. First Draft (FD) (2000)

3. Second Symposium (2000)

4. Second Draft (SD) (2001)

5. Third Symposium (2001)

6. Third Draft (TD, 2002) and SME Promotion Law (SMEPL, 2002)

7. Annex: The Development of the Law's Structure ${ }^{53}$

The third section of the paper is substantively similar to the Procurement Law evaluation discussed above. Selected excerpts from the second section read as follows:

At the first symposium, a Model Law on SME was presented to the Drafting Committee by the Italian scholar Gianmaria Ajani. This Model Law was partly inspired by the recent South Korean legislation on SME Promotion...

On July $4^{\text {th }}$, 2000, the First Draft of an SME Promotion Law was established by the State Economic and Trade Commission ("SETC") on behalf of the FEC and its Drafting Committee. The first draft law is already divided into the six chapters that we will find in the final law (then with an additional seventh chapter added) General Principles: (I) Financial Support (II); Technological Innovation; (III) Market Development; (IV) Service System; (V) and Supplementary Provisions (VI)...

The above-mentioned First Draft was discussed at a second international symposium which was held in Beijing from September 3rd to September 10th, 2000. In addition to the comments on the draft, several more general lectures were held, one of them, by the Swiss scholar Walter A. Stoffel, dealing particularly with legislative technique and the question of how abstract or concrete the future Promotion Law should be, and if it should contain enforceable rights and binding obligations...

The Second Draft was established by the Drafting Committee on April 2, 2001. It took into account most, but not all of the recommendations made in the second symposium's conclusions As for the scope of the law, the Second Draft still does not give a definition of SME, but it does now state the elements to be taken into account by the State Council when doing so, listing namely the total assets, the sales volume and the number of employees; as proposed by the symposium, the Draft also limits its scope to those SME that are not owned by more than $25 \%$ by a large-sixed 
enterprise (art. 2SD). 54

\title{
B. Trainings
}

GTZ also commissions reports to evaluate their trainings also. Although there is some variation, the reports generally contain the following sections; I. Background information about participants; II. Analysis of course materials; III. Overall evaluation of course section; IV. Test scores; V. Assessment of subsequent interviews with participants about 4 months after the course; and VI. Proposals for improving the training course. GTZ also commissions larger reports to evaluate their training programs, such as "Overall Evaluation Report on the First Project Phase of Training and Advisory Service on Economic Laws at the Ministry of Foreign Trade and Economic Cooperation of the People's Republic China." 55

The first section contains a section about the training's participants, for example:

\begin{abstract}
There were totally 40 participants...18 of whom are officials of MOFCOM in Beijing, 10 from subordinate institutions such as the Chinese Academy of International Trade and Economic Cooperation, 3 from different chambers of commerce for import \& export such as China Chamber of Commerce for Import \& Export of Textile, 9 from local Foreign Trade and Economic Bureau such as Shanghai, Guangdong and Qinghai. ${ }^{56}$
\end{abstract}

The second section gives an overview of the contents of that particular training course, for instance "Introduction to the Case Study Method, lecture on Basis Knowledge of Law, Contract Law Case Studies, Introduction to Guarantee law, Guarantee Law Case Studies, Introduction to Foreign Trade Administrative Law \& Other Related Regulations, Introduction to the Agreements of the WTO \& Chinese System accordingly regarding Safeguards, Anti-Dumping and Subsidies." 57

The third section discusses the participants' thoughts about the course, as illustrated through evaluation forms distributed at the end. In these forms participants answered questions such as "Was the subject too difficult? Will the quality of your regular work improve on account of your attendance of this course?" in addition to evaluating the

55 Na Wang, Overall Evaluation Report on the First Project Phase of Training and Advisory Service on Economic Laws at the Ministry of Foreign Trade and Economic Cooperation of the People' s Republic China (2000). 
trainers, interpreters and training materials. 58 Participants rated their trainer's "teaching method, teaching content, availability for communication with participants, co-trainer," in addition to an overall evaluation. 59 Translators were rated with respect to their "accuracy" in addition an overall evaluation. The course's training material rating was broken down into the following categories: "script, cases, solutions, translation of material, quantity," in addition to an overall evaluation.60 On all of these evaluations, participants could provide one of five possible answers: Very Bad, Bad, Medium, Good, and Very Good.61 The forms that the participants filled in also had space for additional comments. 62

The fourth section of each report contained the test scores of the participants. All participants took an initial test and a final exam, and for the longer-term training courses an individual thesis was assigned as homework. 63 For instance, during a judges' training in Kunming, the report states the following with respect to their exams:

The initial test, which was held at the beginning of the course, was aimed at obtaining a rough outline as for the extent of legal knowledge of the participants... there were 19 multiple-choice questions in the initial test (all the questions were to be discussed in the following seminars); the participants were asked to choose the right answers within 15 minutes...

A final test was scheduled at the end of the course, with a purpose of assessing participants' ability to apply legal knowledge and method acquired in the course to problem solving. The test was made up of a single case analysis. The participants were required to analyze the facts given to them in detail and present appropriate answers to the problem set by using the method introduced in the seminar. 64

The fifth section of the report dealt with interviews that occurred about half a year after the training course. One report read:

About a half year after the course, participants were contacted through phone calls, emails and personal meetings by this consultant in order to get feedback on the training course...The evaluation form is designed in the form of questionnaire. The questionnaire includes the following questions:

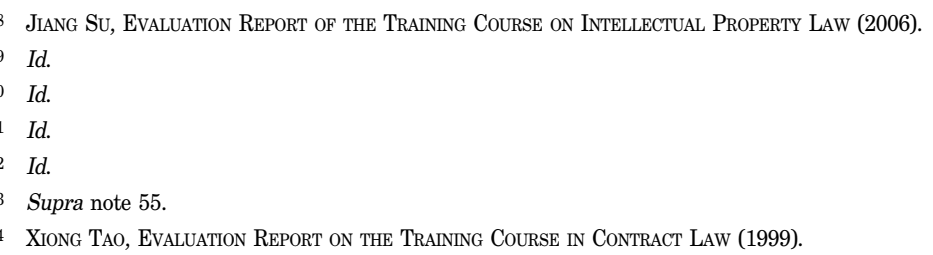


(1) Did the quality of your regular work improve on account of your attendance of the course?

(2) On account of which parts of the course did your regular work improve:

- Introduction to General Principles of Civil Law

- Introduction to the Case Study Method

- Contract law and Case Studies

- Law on Guarantee and Collateral and Case Studies...

(3) Are you able to do your regular work quicker on account of your attendance of the course?

(4) Would your regular work improve if you participated in more courses of this kind?

(5) Did the comparative references to German Law made by the trainer during the course improve your regular work?65

The last section of these reports gives suggestions for future trainings based on the entirety of the report. For instance:

The course as a whole is successful and fruitful since most of the participants had learned much in the course and had applied what they had learned to their daily work. And it should be noted that it was unrealistic and impossible to meet various demands from the participants in such an intensive course. But we still can find some ways to improve the course in order to make it more perfect...

It would be better if a more comprehensive course with all relevant aspects of intellectual property protection can be given. More importantly, the course should be tailored to meet the practical demand of the trainees and most parts of the course should be concentrated on the subsumption technique and case studies rather than theoretical lessons. As for the duration of the course, it will be better if the course can be extended into a longer one (for example a 10-day course) since the participants need more time to learn and practice the subsumption technique. As for the frequency of the course, it will be better if the participants can have subsequent courses (e.g., 2 or 3 subsequent courses) after this course. 66

\section{Symposia}

Although the symposia are evaluated under the larger subheading of "Drafting and Revision of Laws," they are also independently evaluated after they occur. These reports are generally split into four sections: 1 . Aim of the symposium; 2 . Activities; 3. Results/Achievement; and 4. Recommendations/Observations. 67

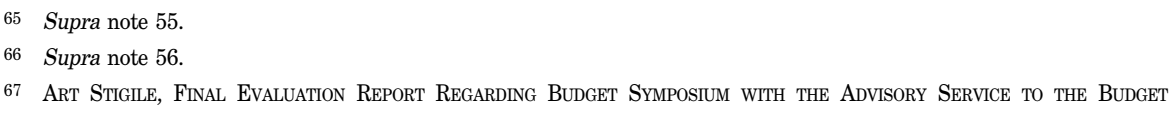


The first section gives background to the symposium and discusses its goals. A representative first section reads as follows:

The primary goal of the project was to provide a forum for a Symposium on the reform of China's Budget Law for a broad spectrum of Chinese government officials consisting of over 70 participants representing all levels of government and various government agencies. The Chinese Budget Law was enacted in 1994 and was amended in 1999. The Budget Law and resulting budget process is recognize to be deficient in several respects, as evidenced by the reports submitted by about 20 Chinese experts and the comments made during the Symposium by the Chinese participants... foreign experts representing Belgium, France, Germany and the United States were invited to make presentations about certain aspects of the budget process in their countries and to participate in the discussions about the Chinese budget process. 68

The second section deals with how the participants prepared for the symposium, its logistics and its implementation. In general, this section is subdivided into five parts: preparation of the assignment, organizational presentation, conditions of the place of initiative, description of the scope, and achievement. 69 A representative sample reads in part:

To prepare for the Symposium, each foreign expert was required to prepare a written paper and a 30 minute presentation about one aspect of the budget process as it exists in their country... The papers were prepared were prepared prior to the Symposium and translated into Chinese for the Chinese participants.

The Symposium was held at Jin Niu State Guest House on the outskirts of Chengdu... The scope of the Symposium was extremely broad, covering all topics of budgeting, including the formulation of agencies' requests, compilation of the budget by the Ministry of Finance, review by Congress, enactment by Congress, implementation by agencies, and financial controls and reporting...

The broad scope of the Symposium and the many long readings of written materials meant that each topic could only be discussed in minimal detail... Thus, the Symposium successfully exposed the Chinese participants to a number of issues and gave them some understanding of how the issues are addressed by other governments... ${ }^{70}$

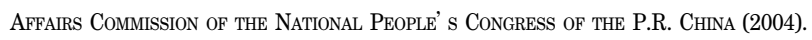


The third section, "results" or "achievement," discusses the outcomes of the symposia. A representative example of the third section reads as follows:

The discussions were remarkably free in tone and choice of subject matters. This ensured contiguous exchanges between Chinese experts and officials and the Western experts... Clearly the Chinese officials were searching for - and finding options for improving and designing key parts of their new budget law. The discussions - to a large extent between Chinese participants - offered a good base for identifying the concrete problems this statute is called upon to help solve...

The cooperation was smooth and very easy; the logistics were well handled. The counterparts knew and expressed what they wanted in terms of information; the German management knew what it wanted and how to obtain it. For instance, the German management drafted a table of content of the main points raised by Chinese counterparts and, using this as a guide, the Western experts wrote a concluding document to the symposium. In particular, I found the GTZ initiative of having this document translated and distributed to participants in a matter of days to be an extremely effective way to ensure that the counterparts fully benefitted from the symposium in drafting the budget law. 71

The fourth section, recommendations, reads similar to the recommendation section cited earlier with respect to trainings:

A slightly lower number of presentations might have made it easier to focus discussions and insure that key concepts and terminology were grasped more quickly by all. For instance, the complementarity (NOT substitutability) of program budgeting and transaction controls (line object budgeting) is everywhere difficult to grasp for people who have had no occasion to observe budgeting in action. A lesser number of communications might have accelerated understanding on such technical but fundamental questions. ${ }^{72}$

\section{Study Tours}

It is unclear how exactly GTZ evaluates its study tours, which may in itself be telling. In some sense, these tours are a part of the "Drafting and Revision of Laws" and evaluated as such, but no documentation was found as to the specific merits of any given tour. This will be discussed in more detail in the analysis section. 


\section{Analysis}

\section{A. Drafting and revision of laws}

On the one hand, GTZ's manner of evaluating their legal advising projects is excellent at gauging the effect of their efforts on the ground. Within these projects, it can point to concrete, indisputable results in the form of actual changes in legislation that is passed by the NPC. This is a clear instance of what rule of law organizations need to have as baseline data in order to see the impact of their programming and the extent to which it furthers their larger goals.

At the same time, within the context of the Chinese legal system, changes in central government legislation are at best tenuously related to actual changes in the implementation of laws in reality. As Peter Corne puts it, "Chinese legislation is often remarkable for its lack of institutional anchoring. Like the policy documents it has come largely to replace, it is often evidently intended more for edification than for litigation, and continues... to contain broad statements of policy and legally unenforceable norms." 73 In addition, although legislation has certainly increased in importance over the past 30 years, the legislative process in China is frequently "divorced from consistent and effective implementation" and the distinction between propaganda and legislation is blurry. ${ }^{74}$

The details of NPC legislation may also be considered somewhat irrelevant in light of the fact that policy experimentation at the local level has been encouraged in China since the reform and opening up era, with many local adaptations later adopted at the national level if successful. 75 As a result, it is common in China - especially in the rapidly evolving domain of economic regulation - for the laws to follow common practice as opposed to vice versa.76 One effect of this process is that lower level bureaucrats fill in the details of central government legislation, which means that any given piece of legislation will have divergent legal effects in different locations in China.77 Local governments are historically accustomed to treating legal proclamations from the center

73 Donald Clarke, Peter Murrell \& Susan Whiting, Law, Institutions, and Property Rights in China, in ChINA's Economy: Retrospect and Prospect $42-44$ (Loren Brandt, Thomas Rawski \& Gang Lin EDs. 2005).

74 Congressional-Executive Commission on China, 2007 Annual Report (2007).

75 See generally Sebastian Heilman, Policy Experimentation in China's Economic Rise, in 43 StudiEs In Comparative INTERNATIONAL DEVELOPMENT (2008).

76 Stanley Lubman, Looking for Law in China, 20 CoLUM. J. AsIAN L. 12 (2006). Lubman gives the example of Contractual Joint Ventures, which were approved by local officials in China for fifteen years before being recognized in national law.

77 Id. at 34 . 
in the same way as they would treat policy pronouncements, 78 which has led some to comment that laws in China are more accurately viewed as general instructions to lower-level government officials than as a means to give notice to the population about the boundaries of legal behavior and the consequences for transgressions.79

One last issue to keep in mind when thinking about the importance of NPC legislation in the Chinese legal context is the prevalence of administrative regulations, which greatly exceeds the number of "laws." 80 GTZ also has trainings of MOFCOM officials who are responsible for these administrative edicts, which will be discussed in more detail in the next section, but the force of administrative law in China should make the impartial observer more skeptical about the impact of NPC legislation.

None of this is to say that changes in NPC legislation are irrelevant; it is simply to say that measuring the effects of legislative revision projects solely in terms of changes to legislation may be insufficient. In other words, in order for GTZ to know whether its modifications to the articles Government Procurement Law led to any actual difference on the ground, it would need to extend their analysis beyond the text of the law. For instance, GTZ could evaluate whether local governments' interpretations of NPC legislation reflected some of the comments that GTZ's experts put forward, or see if the changes they suggested led to any interesting policy experimentation on the local level. If this were the case, then GTZ could genuinely say that their drafting and revision work led to development in the rule of law in China.

To be fair, one should keep in mind that part of GTZ's work is to export German laws and regulations to China. Thus, insofar as GTZ is successful in influencing Chinese legislation on the books - the framework in which the Chinese legal system operates - it can consider itself a success. However, if the "German" laws on the books are not enforced on the ground, then the importance of GTZ's accomplishment may be minimized.

Also relevant is the fact that GTZ signs long-term partnerships with Chinese Ministries, often with the specific content to be agreed upon later. On the plus side, this enables GTZ to respond to the "hot topics" of the day and adjust their projects to their partners' changing demands. The downside of this approach is twofold: first, GTZ often must switch projects before it can be entirely sure that its prior work was successful; secondly, since GTZ's partners function on the national level, it is difficult for the organization to examine how central legislation is being implemented in different localities.

\footnotetext{
Stanley Lubman, Bird in a Cage: Legal Reform in China after Mao 38 (2000).

Id. at 146 .

Randall Perenboom, China's Long March toward Rule of Law 241 (2002).
} 
Lastly, the question of cost-efficiency must be addressed whenever considering the extent to which an organization should invest in monitoring and evaluation. This is especially the case in China, as Dr. Julius, GTZ Legal Advisory's country director, is quick to point out, in which many other reputable international organizations are regularly reporting on the situation on the ground. For instance, Transparency International, the World Bank, the Organization for Economic Cooperation and Development and countless universities and scholars continually research the NPC law's implementation on the ground, so for GTZ to do so also might be considered redundant. In addition, GTZ's main donor (the Ministry for Economic Development and Cooperation) does not require it to directly tie changes on the ground to its own work; the Ministry requires that it show that the changes on the ground are harmonious with its projects.

\section{B. Trainings}

GTZ's evaluations of their judicial and administrative trainings' teachers, interpreters, and materials are thorough and on the mark. In addition, their evaluation of the participants' subjective experience of the trainings is extensive. However, what GTZ currently lacks is a method of seeing the extent to which these trainings actually change the behavior of participants in the course of their daily functioning in the Chinese legal system.

For instance, with respect to the judges' trainings, GTZ currently has no way of knowing whether or not the judges' judicial opinions change as a result of its courses. This is a glaring omission, especially in light of the variegated influences on Chinese courts that are entirely external to the legal domain. Although the Chinese constitution clearly states that the courts ought "act in accordance with law, exercise judicial power independently... and are not subject to interference by administrative organs, public organizations and individuals," 81 in practice, courts are entirely beholden to local governments for their financing,, 82 and judges are appointed and promoted by the CCP based on their judicial performance. 83

The local government controls all financial matters of the courts, and the court is often called upon to help enforce local government priorities such as the collection of taxes and the promotion of economic development.84 This leads courts to be especially hesitant to rule against local State Owned Enterprises or to take any action that might

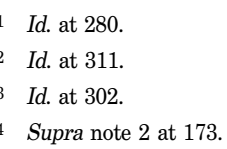


lead to job losses or social unrest. In addition, the courts are accountable to the Procuracy, which is charged with the prosecution of criminal matters. In addition to higher-level courts, the Procuratorate has the power to review decisions that it finds to be in conflict with the law. 85 Also, deputies in the Local People's Congresses are increasingly exerting their powers of supervision over the courts, and judges are weary to upset those with political connections to higher-ups in the government or the party. 86

In addition, although legal training has become more prominent among a judge's qualifications, the willingness to "safeguard state, collective and individual interests" is still a prerequisite. 87 Judges' adherence to this principle is ensured by the CCP, which has control over their appointment in the first place and their career advancement in the second. 88 As such, what is often more determinative of a judge's success within the Chinese legal system is his political moxie rather than his legal abilities, which is partially reflected in the fact that court presidents, the court's highest authority, often have no legal background at all. 89

Further undermining judicial independence, and as such, the possible efficacy of GTZ' s judges' trainings is the fact that judges can be punished and sometimes even fined when their decisions are reversed on appeal, which leads them to be very cautious in handling all matters. 90 Traditionally, all court decisions traditionally had to be approved by the court president and adjudication committee, and although judges now have more freedom in deciding cases on their own, fear of disapproval and higher-level punishment is rampant. As such, it is still common for judges to seek the opinions and inputs of higher-level judges and their court president to ensure that their actions are acceptable. 91

Lastly, one factor that must be always kept in mind when considering whether GTZ trainings modify judicial behavior in China is corruption, which - as is true in most other areas of China's Party State - is endemic. ${ }^{92}$ There is no independent bar to regulate judges, 93 and the very same notion of guanxi (connections) that permeates and influences the rest of Chinese government applies with equal force to the judiciary, as

91 Supra note 76.

92 Donald C. Clarke, The Role of Law in China's Economic Development, George Washington UnIVERSITY LaW School WORKING PAPER 22, 187 (2006). 
the work from judges is not much distinguished from the rest of the bureaucracy. ${ }^{94}$ In addition, judges' low salaries invite bribery,95 especially in economic cases in which large sums are at stake. Certain regions of China such as Shanghai, which boast better educated and better paid judges, have less corruption, but even Shanghai has failed to implement many reforms necessary for an independent and fair judiciary. 96

With all this in mind, it is clear that GTZ cannot simply rely on a form that participants fill out six months after a legal training to gauge whether or not it actually had an effect on their work. One possible way that GTZ can better evaluate its trainings would be to request judicial opinions from the judges both before and after the trainings. Although some judicial opinions would be difficult to access, several Supreme People's Court opinion in 2003 called for greater accessibility (in addition to higher quality) of judicial opinions. ${ }^{97}$ Granted, if judges self-selected to submit their opinions to GTZ, the sample would not be representative of all of the judges at the training. In addition, discerning the influence of a judges' training on any particular judicial opinion is far from straightforward and can be time-intensive. However, some gesture in this direction would be an improvement, and only if GTZ takes this type of step will it be able to say that their judges' trainings actually influence the functioning of Chinese courts and bureaucracy.

A great idea that emerged during discussions with Dr. Julius, though with respect to its MOFCOM trainings not its judicial ones, was to examine MOFCOM's anti-monopoly judgments in the coming years. Although only its refusals are published (i.e. its rulings that proposed mergers would constitute monopolies), these alone offer a window into how MOFCOM bureaucrats are developing and whether they are putting into practice skills learned at GTZ trainings. In addition, based on earlier efforts in Central Asia, GTZ in Beijing plans to start analyzing some of its judicial opinions in 2010. In this way, GTZ will be able to learn about the strengths and weaknesses of these trainings and adapt accordingly.

\section{Symposia}

GTZ has very good means of evaluating the impact of its symposia on the NPC's drafting and revision of laws. It is clear how its symposia address problems in the drafting process as they arise and the eventual impact they have on NPC legislation. Thus, the only issue that remains, as discussed in section (a), is the actual impact that

\footnotetext{
94 Supra note 80 , at $278-9$.

95 Id.

96 See generally Mei Gechlik, Judicial Reform in China: Lessons from Shanghai, 19 Colum. J. AsIAN L (2005).

97 Congressional-Executive Commission on China, 2007 Annual Report (2007).
} 
legislative modification has on the ground.

\section{Study Tours}

The fact that it is unclear how GTZ evaluates their study tours is telling. Although these activities play into the drafting and revision of legislation in a manner similar to symposia, they are not mentioned in the final evaluations of the drafting and revision projects. 98 Study tours have been heavily criticized for their questionable programmatic value and for the fact that they "are [often used] as leisure trips and remunerations for higher ranking cadres not exclusively interesting in studying foreign legal systems in their respective countries of origin." 99 More fully put,

The value of study tours as an opportunity for Chinese participants to learn more about the donor nation' $s$ legal system in practice very often is flawed by the fact that, firstly, these tours are usually only very short; a stay of about two weeks does not leave much room for thoroughly acquainting the Chinese participants with the foreign legal system. Secondly, when fixing the programs for the tours, foreign, foreign donor organizations are careful to calculate enough time for shopping and sightseeing at the request of the Chinese side...

Anecdotal evidence adds to this argument: Very often some study tour destinations which are proposed by donors because of being important and interesting due to the fact that they harbor important judicial institutions (high-level courts, research institutes, renowned legal scholars and university institutes, etc.) are rejected by the Chinese counterparts. The reason for this rejection very often lies in the fact that some of the Chinese counterpart already participated in prior study tours to the same locations and now want to take the opportunity to come to know different touristy attractive parts of the donor country. 100

To be fair, study tours may be a good way to promote good relations with Chinese counterparts, as AT\&T was known to do throughout the 80s and 90s.101 While in China, companies like AT\&T tried "to focus on helping their Chinese partners, suppliers and customers become more sophisticated and international." 102 In arranging overseas tours for Chinese business and government counterparts that mixed "facility tours, business Actors' Interests, 42 ChINA ANALYsis: STUdiEs IN POLITICAL Economy, available at http://www.chinapolitik.de/studien/ china_analysis/no_42.pdf (last visited on Oct. 8, 2009).

100 Id.

101 James McGregor, One Billion Customers: Lessons from the Front Lines of Doing Business in China 118 (2005).

102 Id. 
seminars and training courses with generous opportunities for tourism and relaxation," AT\&T "engendered lots of goodwill." 103

In addition, Dr. Julius points out, by conducting study tours GTZ gains access to higher-level officials, many of whom would never attend a local training. When GTZ has these leaders' ears, it can put sensitive topics on the table and influence the government in subtle but important ways. Moreover, a study tour provides a relaxed, casual setting during which GTZ employees and Chinese officials can mingle and build personal friendships, friendships that often prove to be vital to GTZ's work. In addition, Chinese officials can use study tours as gifts to be distributed within a bureaucracy to curry favor, much like the free laptops of other development organizations. Lastly, on the point of expense, GTZ does not cover all costs of the Chinese participants, such as international airfare or per diems.

That being said, if GTZ wanted to expose Chinese counterparts to foreign legal systems in a more substantive manner, GTZ could implement a program such as the Yale China Law Center's, through which Chinese scholars spend a year or more researching particular legal questions at Yale's facilities.104 Then again, as Dr. Julius points out, a long-term program such as Yale's only attracts young attorneys, scholars and government officials, whereas one of the key benefits of study tours is access to high-level individuals. In addition, he points out, GTZ has a program similar to Yale's in that it sends 12-15 Chinese law students to Germany to get LLM's. That being said, as things stand now, the manner in which GTZ's study tours help it to achieve its rule of law aims is at best unclear.

\section{Conclusions}

Rule of law programs have been in existence for almost a half-century, but fundamental questions remain unaddressed. Among these is the net effect of rule of law projects on the ground, and the connection between these results and promoting the rule of law in general. Thus, if a development organization is not properly and effectively monitoring its progress in real terms, it will be unable to move forward in a methodical and precise manner toward its goals.

GTZ is an organization with a strong China background and a healthy amount of

103 Id. at 119 .

104 Yale LaW School, The China LAW CENTER, available at http://www.law.yale.edu/intellectuallife/clcvisitingscholars.htm (last visited on Oct. 8, 2009). 
resources. Moreover, it effectively monitors the impact of much of its work, and as such is able to know in what way its projects succeed and in what way they fall short. For instance, GTZ knows the exact influence that its advising and symposia have on the text of central government legislation. However, with respect to some programming, GTZ cannot draw a direct connection between their efforts and any particular impact on the Chinese judiciary. For example, it is unclear if judges' trainings increase the competence of the judiciary or if study tours lead to a greater understanding of international approaches to common problems.

With respect to these latter programs, GTZ is vulnerable to Jensen and Heller's critique that it pays insufficient attention to "measuring baselines of performance and the interconnectedness of social, economic, political and legal development." 105 At the same time, if GTZ were to devote more resources to monitoring and evaluation, it would have fewer resources to devote to its projects. The ultimate decision as to what percentage of an organization's budget to set aside for monitoring and evaluation will always involve the politics of its donors and the organization itself; for instance, if GTZs donors required it to demonstrate a direct connection between its programming and changes on the ground, then GTZ would modify its evaluation methods. Regardless of donor requirements, however, a development organization should never view monitoring and evaluation funds as funds that could have been spent on programming; rather, it should view monitoring and evaluation funds as the organization's attempt to ensure that its programming funds are not spent in vain. 